\title{
William Eldon Tucker, FRCS, CVO, MBE, TD
}

Full obituaries have already been published elsewhere detailing Bill's astounding career as an orthopaedic surgeon. His patients included the Royal Family as well as many of the leading cricketers and tennis players of the decades after World War II until the late 1970s. Little, however, has been written in the national press about his 40 years' service to the British Association of Sport and Medicine, of which he was a founder member in 1952 and remained a member until his death in August 1991. In 1936, at the age of 33, he opened the Park Street Orthopaedic Clinic in which he pioneered the treatment of sports injuries, stimulated largely by his own experience as a rugby international, so he was an obvious choice when Sir Adolphe Abrahams and Sir Arthur (now Lord) Porritt gathered together a small group of doctors interested in sport and medicine to form a 'British branch of the International Sports Medicine Federation' which became the British Association of Sport and Medicine (BASM) on its formal inception. $\mathrm{He}$ served on the Executive Committee almost continuously until he retired to Bermuda (where his family had been prominent colonists since the 17th Century) in the late 1970s.

In 1965 BASM, the British Olympic Association and the Physical Education Association jointly founded the Institute of Sports Medicine (not to be confused with the new National Sports Medicine Institute), and Bill, together with Sir Arthur Porritt, Dr Denis Cussen (the Honorary Secretary of BASM), Dr John G. P. Williams and myself were appointed as BASM's representatives on the board of management of this institute founded for the promotion of sports medicine knowledge. BASM's official representation, however, ceased after 3 or 4 years. In 1969 Bill was elected an Honorary Life Member of BASM in recognition of his services to the association and to sports medicine generally, and in 1978 he was elected a Vice President, an office he held until his death. Even after his retirement to Bermuda he tried to encourage the organization of a sports medicine service for the island.

Apart from his well known books and articles on sports injuries and their prevention through active alerted posture and Injury in Sport, written with J. M. Armstrong, he contributed articles to this journal and a memo to the Executive Committee in 1979 propounding the need for adequate medical supervision at all sporting events, and suggesting ways in which this could be done. During the time I knew him, he got enormous support from his second wife, the journalist and author Molly Castle, who was

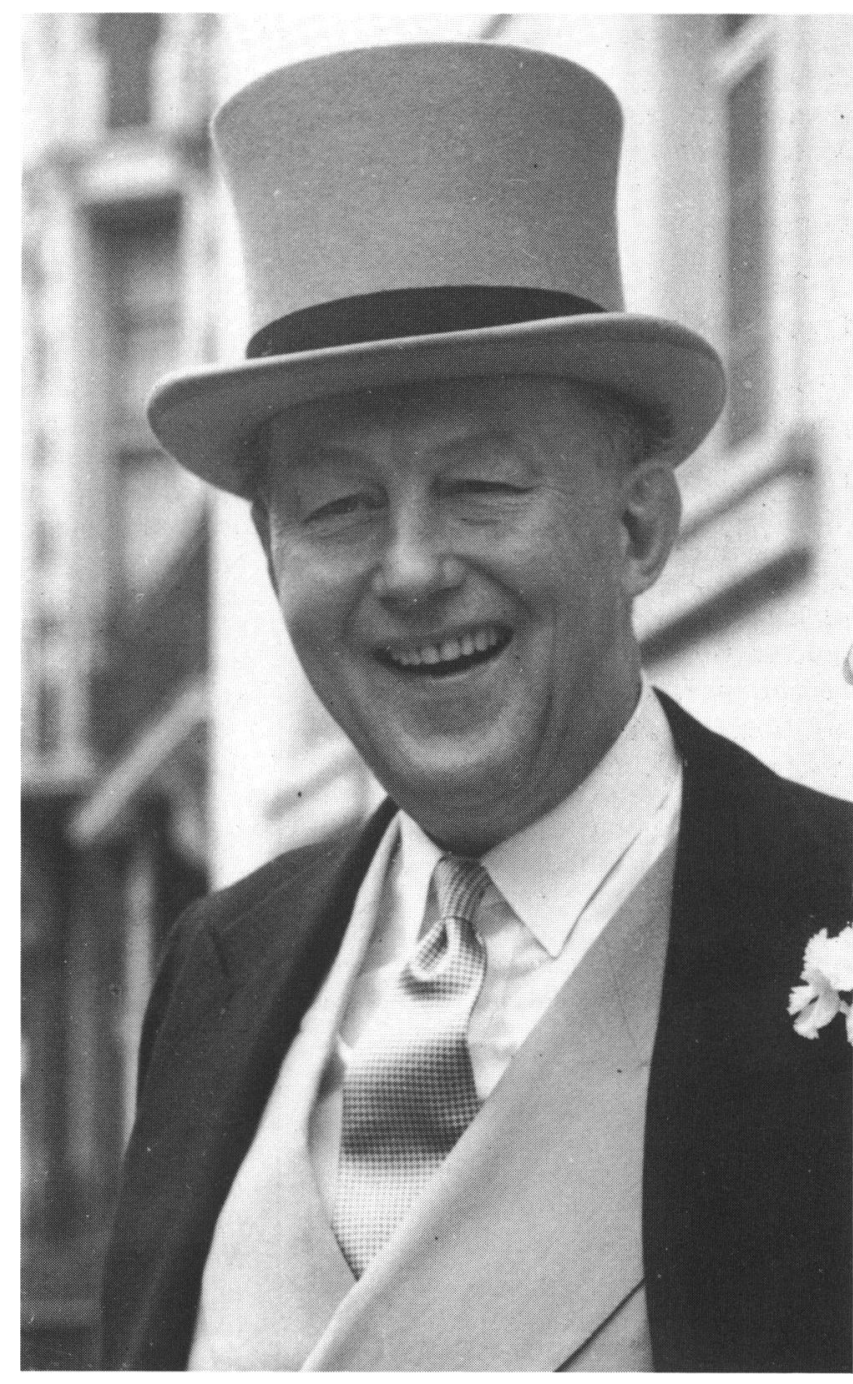

Reproduced with the kind permission of The Hulton Picture Company

co-author of several of his books. Molly's death in 1987 was a severe blow from which he never appeared to recover.

He died in Bermuda in August, and a memorial service was held in St. Mary's Church, Bryanston Square, London on 2 October 1991. BASM has lost one of its most enthusiastic pioneers, and I have lost a good and long-standing friend.

Henry Robson Vice President, BASM Editor Emeritus, BJSM 